\title{
Penguatan Pendidikan Karakter di SD
}

\author{
Ilham Nur Sujatmiko ${ }^{1}$, Imron Arifin ${ }^{1}$, Asep Sunandar ${ }^{1}$ \\ ${ }^{1}$ Manajemen Pendidikan-Universitas Negeri Malang
}

\section{INFO ARTIKEL}

\section{Riwayat Artikel:}

Diterima: 31-07-2019

Disetujui: 22-08-2019

\section{Kata kunci:}

character building; elementary school students; implementation of character education;

pendidikan karakter; siswa sekolah dasar; implementasi pendidikan karakter

\section{Alamat Korespondensi:}

Ilham Nur Sujatmiko

Manajemen Pendidikan

Universitas Negeri Malang

Jalan Semarang 5 Malang

E-mail: ilhammiko06@gmail.com

\section{ABSTRAK}

Abstract: This study aims to (1) Describe the strategy and implementation of strengthening class-based character education at SD Muhammadiyah 08 Dau and MI Miftahul Ulum Sudimoro (2) Explain the strategy and implementation of strengthening culture-based character education at SD Muhammadiyah 08 Dau and MI Miftahul Ulum Sudimoro (3) Describe the supporting and inhibiting factors for the success of strengthening character education in SD Muhammadiyah 08 Dau and MI Miftahul Ulum Sudimoro. Data is collected through interviews, observation and documentation. The results of the study are (1) Strengthening class-based Character Education in SD Muhammadiyah 08 Dau Malang and MI Miftahul Ulum Sudimoro conducted by referring to the vision and mission, analysis of Basic Competence, Learning Planning, Classroom Arrangement, Class Regulation Planning, Management of Student Work, Management of Inappropriate Student Behavior (2) Strengthening class-based Character Education at SD Muhammadiyah 08 Dau Malang and MI Miftahul Ulum Sudimoro conducted by including school programs that have religious values, integrity, nationalism, mutual cooperation, independence, formation of institutions, involvement of stakeholders, establishment of school rules, literacy (3) Success in Strengthening Character Education has supporting and inhibiting factors both internally and externally. the internal support of the teacher has a character that deserves to be used as a report, internal barriers some teachers lack understanding of the K-13 curriculum, external support of student guardians participate in the role in strengthening the character education of students, external obstacles some guardians are indifferent to the character of the students

Abstrak: Penelitian ini bertujuan untuk (1) mendeskripsikan strategi dan impelementasi penguatan pendidikan karakter berbasis kelas di SD Muhammadiyah 08 Dau dan MI Miftahul Ulum Sudimoro (2) Menjelaskan strategi dan impelementasi penguatan pendidikan karakter berbasis budaya di SD Muhammadiyah 08 Dau dan MI Miftahul Ulum Sudimoro (3) Mendeskripsikan faktor pendukung dan penghambat keberhasilan penguatan pendidikan karakter di SD Muhammadiyah 08 Dau dan MI Miftahul Ulum Sudimoro. Data dikumpulkan melalui wawancara, observasi, dan dokumentasi. Hasil penelitian adalah (1) Penguatan Pendidikan Karakter (PPK) berbasis kelas di SD Muhammadiyah 08 Dau Malang dan MI Miftahul Ulum Sudimoro dilakuakan dengan mengacu kedalam visi misi, analisis Kompetensi Dasar, Perencanaan Pembelajaran, Pengaturan Ruangan Kelas, Perencanaan Peraturan Kelas, Pengelolaan Pekerjaan Peserta Didik, Pengelolaan Perilaku Peserta Didik yang Tidak Pantas (2) Penguatan Pendidikan Karakter (PPK) berbasis kelas di SD Muhammadiyah 08 Dau Malang dan MI Miftahul Ulum Sudimoro dilakukan dengan memasukkan kedalam program sekolah yang memiliki nilai religius, integritas, nasionalis, gotong royong, mandiri, pembentukan suritauladan, keterlibatan pemangku kepentingan, pembentukan tata tertib sekolah, literasi (3) Keberhasilan Penguatan Pendidikan Karakter (PPK) memiliki faktor pendukung dan penghambat baik secara internal dan eksternal. pendukung internal guru mempuyai karakter yang patut dijadikan suritauladan, penghambat internal beberapa guru kurang memahami kurikulum K-13, pendukung eksternal wali murid ikut perperan dalam penguatan pendidikan karakter peserta didik, penghambat eksternal beberapa wali murid acuh tak acuh dengan karakter peserta didik 
Pendidikan karakter merupakan gabungan dari dua kata yakni pendidikan dan karakter, menurut Ki Hajar Dewantara pendidikan karakter adalah daya ataupun upaya untuk memajukan pikiran, jasmani dan juga budi pekerti supaya selaras dengan lingkungan sekitar dan juga alam (Dalimunthe, 2015). Dengan upaya menyiapkan generasi emas pada tahun 2045 nanti yang senantiasa bertaqwa, nasionalis, tangguh dan juga mandiri adalah cita-cita Bangsa Indonesia, namun perlu upaya untuk mewujudkannya karena permasalahan sosial yang akhir-akhir ini kita dengar adalah tentang tawuran para pelajar di Indonesia. Betapa maraknya permasalahan yang terkait dengan dunia pendidikan. Permasalahan yang lain diantaranya adalah degradasi moral, akhlaq dan budi pekerti yang kini ada di lingkungan pendidikan, misalnya saja adalah mencotek teman pada saat ulangan, tidak patuh pada nasehat guru, tidak mau bersalaman ketika bertemu dengan guru, membuka pintu tanpa mengucapkan salam, tidak bertegur sapa ketika bertemu dengan guru, berbicara lantang ketika dengan orang yang lebih tua, tidak segera melaksanakan sholat dan masih banyak lainnya. Hal ini menunjukkan kurangnya keberhasilan penguatan pendidikan karakter di sekolah bersama guru maupun dirumah dengan orangtua serta lingkungan dengan masyarakat.

Generasi emas 2045 berupaya mengembangkan sikap positif yang berlandaskan IESQ sehingga generasi 2045 nantinya mempunyai mental yang siap untuk bersaing dengan negara-negara maju lainnya (Manullang, 2013). Akan tetapi, masalah saat ini tidak bisa dibiarkan berlarut larut karena penguatan pendidikan karakter yang masih sangat lemah untuk saat ini. Seharusnya anak sudah mendapatkan pendidikan karakter sedini mungkin sehingga kelak anak dapat menggelola sikap kognitif, afektif dan juga psikomotor (Shoimah, Sulthoni, \& Soepriyanto, 2018). Sehingga kelak akan menjadi manusia yang berkualitas yang tentunya dapat mendorong kemajuan suatu bangsa menjadi lebih baik. Cara yang kurang tepat sangat memengaruhi degradasi ini, misalnya dari sistem sekolah yang memang saat ini sudah kearah intelektualitas, kurang memperhatikan moralitas. Hal tersebut bisa dilihat dengan adanya sistem ujian, yang menjadi patokan adalah nilai kognitif peserta didik tanpa memperhatikan aspek afektif..

Lembaga sekolah saat ini menjadi tumpuan yang sangat besar dalam menguatkan pendidikan karakter melalui berbagai macam strategi, termasuk diantaranya adalah kurikukum, penegakan disiplin, manajemen kelas, baik melalui progam progam sekolah yang sudah dicanangkan (Isbadrianingtyas, Hasanah, \& Mudiono, 2016). Strategi sendiri adalah cara cara yang digunakan untuk mencapai tujuan. Menurut (Andiarini \& Nurabadi, 2018) pada dasarnya dari sekolahlah karakter peserta didik dapat dibentuk dengan melaksanakan program-program yang telah dibuat sekolah untuk penguatan pendidikan karakter pada peserta didik, seperti yang dilaksanakan oleh SD Muhammadiyah 08 Dau dan MI Miftahul Ulum Sudimoro. Pembentukan karakter pada anak sekolah dasar dapat dibentuk dengan cara menanamkan pedidikan karakter secara konsisten baik dari keluarga, dari sekolah maupun dari lingkungan masyarakat sekitar (Kurniawan, 2015).

Mengingat pentingnya menguatkan pendidikan karakter ini di era 4.0 yang mungkin sisi humanis akan sedikit hilang maka perlu diadakannya kerjasama antara berbagai pihak termasuk diantaranya adalah pihak sekolah, keluarga dan lingkungan. Dimana di era ini terjadi perubahan peradaban masyarakat yang ditandai dengan berubahnya sendi-sendi kehidupan, kebudayaan, kemasyarakatan termasuk juga pendidikan. Guru sebagai sumber ilmu juga harus menggerti teknologi yang berkembang pada saat ini supaya bisa membimbing ataupun mengarahkan peserta didik supaya tidak terjerumus pada teknologi yang modern pada saat ini (Wijanarti, Degeng, \& Untari, 2019)

Wawasan yang luas untuk menghadapi era globalisai ini diperlukan suatu wadah untuk menyampaikannya, yaitu melalui bidang pendidikan, karena pendidikan merupakan suatu upaya untuk pembentukan manusia-manusia muda. Pendidikan merupakan suatu pilar dimana adanya tindakan edukatif dan didaktif bagi pelakunya. Pendidikan ini juga bisa sebagai proses penyempurnaan diri manusia secara terus-menerus. Pendidikan yang berhubungan dengan pembentukan moral dan etika ini adalah pendidikan karakter. Pendidikan karakter ini memiliki sebuah tujuan yaitu membentuk suatu kepribadian seseorang yang berkeutamaan di sekolah pengembangan kepribadian seorang anak tidak hanya menyangkut ada satu aspek kognitif saja, melainkan aspek, afektif dan psikomotorik. Pendidikan yang dikira kurang mampu dalam mengembangkan moral peserta didik karena saat ini praktik dalam bidang pendidikan tidak lebih dari latihan-latihan skolastik seperti halnya mengenal, membandingkan, melatih dan menghafal (Asriani \& Sa'dijah, 2017). Sekolah harus mempunyai strategi untuk mengatasi krisis karakter melalui Penguatan Pendidikan Karakter (PPK). PPK ini harus mengembangkan lima nilai karakter termasuk diantaranya adalah religius, nasionalisme, kemandirian, gotong royong, dan integritas. Krisis karakter seperti ini dapat diatasi melalui pengintegrasian melalui kegiatan intrakurikuler, ekstrakulikuler. Setiap sekolah tentunya mempunyai budaya yang beraneka ragam akan tetapi semua sekolah mempunyai tujuan yang sama yakni membentuk karakter peserta didik yang mengerti norma dan juga adab dan tentunya kegiatan sekolah juga bibentuk sebagai motivator atau penyemangat bagi peserta didik (Puri, Nurkholipah, \& Putri, 2017).

\section{METODE}

Pendekatan dalam penelitian ini menggunakan pendekatan kualitatif, dengan menggunakan jenis penelitian studi kasus yang berusaha untuk menggambarkan suatu keadaan saat ini. Dapat dijelaskan bahwa penelitian kualitatif ini merupakan penelitian yang datanya berupa kata-kata yang memiliki karakteristik sendiri karena tidak memuat angka-angka sebagai data. Penelitian kualitatif ini lebih melihat pada keadaan yang sebenarnya terjadi di lapangan, bukan keadaan yang seharusnya terjadi 
di lapangan. Pendekatan dalam penelitian ini menggunakan pendekatan kualitatif, dengan menggunakan jenis penelitian studi kasus yang berusaha untuk menggambarkan suatu keadaan saat ini. Dapat dijelaskan bahwa penelitian kualitatif ini merupakan penelitian yang datanya berupa kata-kata yang memiliki karakteristik sendiri karena tidak memuat angka-angka sebagai data. Penelitian kualitatif ini lebih melihat pada keadaan yang sebenarnya terjadi di lapangan, bukan keadaan yang seharusnya terjadi di lapangan.

Dalam penelitian ini, peneliti bekerjasama dengan sekolah baik di SD Muhammadiyah 08 Dau maupun dengan MI Miftahul Ulum Sudimoro untuk dapat mewawancarai kepala sekolah, wakil kepala sekolah bagian kurikulum, wakil kepala sekolah bagian kesiswaan, guru kelas I dan IV dalam rangka memperoleh informasi terkait tujuan penelitian.

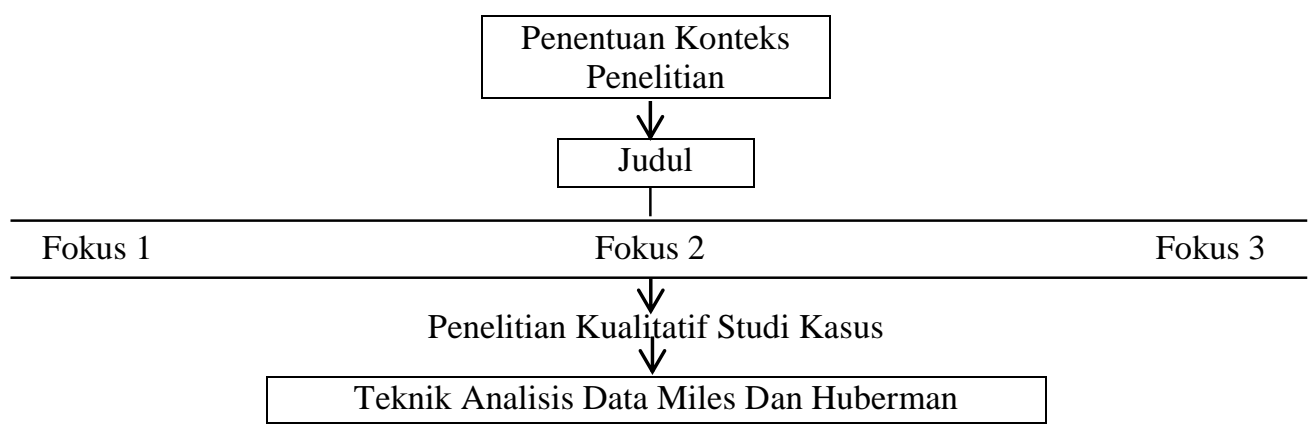

\section{Gambar 1. Alur Penelitian}

Alur penelitian dimulai dengan peneliti mencari konteks penelitian yang sekarang lagi marak di dunia pendidikan yakni mulai memudarnya karakter peserta didik. selanjutnya peneliti menentuka judul yakni "Penerapan Penguatan Pendidikan Karakter Di SD Muhamadiyah 08 Dau dan Mi Miftahul Ulum Sudimoro" dan dilanjutkan dengan fokus penelitian apa yang mau diteliti oleh peneliti yang berjumlah tiga buah fokus masalah (1) Bagaimana strategi dan impelementasi penguatan pendidikan karakter berbasis kelas di SD Muhammadiyah 08 Dau dan MI Miftahul Ulum Sudimoro (2) Bagaimana strategi dan impelementasi penguatan pendidikan karakter berbasis budaya sekolah di SD Muhammadiyah 08 Dau dan MI Miftahul Ulum Sudimoro (3) Apa faktor pendukung dan penghambat keberhasilan penguatan pendidikan karakter di SD Muhammadiyah 08 Dau dan MI Miftahul Ulum Sudimoro. Setelah sang peneliti menemukan fokus apa yang akan diteliti, maka akan dilanjut dengan penelitian yang menggunakan penelitian kualitatif studi kasus yang akan dilaksanakan di SD Muhammadiyah 08 Dau dan MI Miftahul Ulum Sudimoro dengan menggunakan analisis data Miles dan Huberman.

HASIL

Tabel 1. Hasil Fokus Masalah 1

\begin{tabular}{|c|c|c|c|c|}
\hline \multirow[t]{2}{*}{ Pertanyaan } & \multicolumn{2}{|l|}{$\begin{array}{r}\text { Siklus I } \\
\end{array}$} & \multicolumn{2}{|l|}{$\begin{array}{r}\text { Siklus II } \\
\end{array}$} \\
\hline & Persamaan & Perbedaan & Persamaan & Perbedaan \\
\hline $\begin{array}{l}\text { Strategi /program dalam } \\
\text { Penguatan Pendidikan Karakter } \\
\text { (PPK) terkait visi dan misi } \\
\text { sekolah }\end{array}$ & $\begin{array}{l}\text { Adanya program-program } \\
\text { sekolah yang mengandung nilai } \\
\text { lima karakter baik sasaran guru } \\
\text { maupun peserta didik }\end{array}$ & - & $\begin{array}{l}\text { Adanya program-program sekolah } \\
\text { yang mengandung nilai lima } \\
\text { karakter baik sasaranna guru } \\
\text { maupun peserta didik }\end{array}$ & \\
\hline $\begin{array}{l}\text { Telaah Nilai-Nilai Penguatan } \\
\text { Pendidikan Karakter dalam KD } \\
\text { dan Mata Pelajaran, melalaui } \\
\text { Analisis KD } \\
\text { Strategi/program Penguatan } \\
\text { Pendidikan Karakter terkait } \\
\text { dengan analisis KD }\end{array}$ & $\begin{array}{l}\text { Ada pengembangan } \\
\text { Kompetensi Dasar }\end{array}$ & - & $\begin{array}{l}\text { Belum ada program khusus namun } \\
\text { guru berusaha mengembangkan } \\
\text { Kompetensi Dasar untuk } \\
\text { penanaman nilai karakter }\end{array}$ & - \\
\hline $\begin{array}{l}\text { Pengintegrasian Penguatan } \\
\text { Pendidikan Karakter dalam } \\
\text { Perencanaan Pembelajaran } \\
\text { strategi/program Penguatan } \\
\text { Pendidikan Karakter terkait } \\
\text { dengan model pembelajaran }\end{array}$ & $\begin{array}{l}\text { Perombakan Rencana } \\
\text { Pelaksanaan Pembelajaran } \\
\text { Model pembelajaran } \\
\text { disesuaikan dengan materi dan } \\
\text { tema }\end{array}$ & - & $\begin{array}{l}\text { Menyusun RPP, dan kemudian } \\
\text { model pembelajaran disesuaikan } \\
\text { tema dan materi yang akan } \\
\text { disampaikan }\end{array}$ & \\
\hline
\end{tabular}


Tabel 1. Hasil Fokus Masalah 1 (Lanjutan)

\begin{tabular}{llc}
\hline $\begin{array}{l}\text { Penguatan Pendidikan Karakter Berbasis } \\
\text { Kelas dalam Pengaturan Ruang Kelas }\end{array}$ & $\begin{array}{l}\text { Strategi dan implentasinya adalah } \\
\text { penyediaan ruang kelas, dan bangku serta } \\
\text { cara berinteraksi sesuai dengan nilai PPK }\end{array}$ & $\begin{array}{l}\text { Pengaturan ruang kelas termasuk fisik } \\
\text { dan non fisik disesuaikan dengan tema } \\
\text { dan materi yang diajarkan }\end{array}$ \\
\hline $\begin{array}{l}\text { Penguatan Pendidikan Karakter Berbasis } \\
\text { Kelas dalam merencanakan peraturan } \\
\text { kelas }\end{array}$ & $\begin{array}{l}\text { Mengandung nilai religius, nasionalis, } \\
\text { gotong royong, mandiri, integritas dan } \\
\text { mendapatkan hukuman bagi yang melanggar }\end{array}$ & $\begin{array}{c}\text { Adanya kesepakatan antara guru dan } \\
\text { peseta didik diawal semester }\end{array}$ \\
\hline $\begin{array}{l}\text { Pendidikan Karakter Berbasis Kelas } \\
\text { dalam prosedur pengelolaan pekerjaan } \\
\text { peserta didik }\end{array}$ & $\begin{array}{l}\text { Dilakukan komunikasi yang baik dengan } \\
\text { peserta didik }\end{array}$ & $\begin{array}{l}\text { Adanya sosialisasi terlebih dahulu } \\
\text { dalam penerapan aturan }\end{array}$ \\
\hline $\begin{array}{l}\text { Guru mengelolah perilaku peserta didik } \\
\text { di dalam kelas yang tidak pantas dalam }\end{array}$ & Memberikan hukuman bagi yang melanggar & Memberikan denda atau hukuman \\
$\begin{array}{l}\text { Penguatan Pendidikan Karakter } \\
\text { sesuai kesepakatan bagi yang } \\
\text { melanggar }\end{array}$ & -
\end{tabular}

Tabel 2. Hasil Fokus Masalah 2

\begin{tabular}{|c|c|c|c|c|}
\hline \multirow[t]{2}{*}{ Pertanyaan } & \multicolumn{2}{|l|}{ Siklus I } & \multicolumn{2}{|l|}{ Siklus II } \\
\hline & Persamaan & Perbedaan & Persamaan & Perbedaan \\
\hline $\begin{array}{l}\text { Strategi /programPenguatan Pendidikan } \\
\text { Karakter dengan cara menanamkan nilai- } \\
\text { nilai utamanya dari segi religious, } \\
\text { integritas, nasionalis, gotong royong, } \\
\text { mandiri yang dilakukan dalam kegiatan } \\
\text { sehari hari }\end{array}$ & $\begin{array}{l}\text { Kegiatan rutin harian } \\
\text { berbaris di depan kelas } \\
\text { menumbuhkan karakter } \\
\text { disiplin } \\
\text { Kegiatan sholat Dhuha } \\
\text { Upacara bendera saat hari } \\
\text { senin } \\
\text { Menyanyikan lagu } \\
\text { kebangsaan Indonesia } \\
\text { Raya menumbuhkan } \\
\text { karakternasionalis } \\
\text { Membaca Asmaul Husna } \\
\text { menumbuhkan karakter } \\
\text { religius }\end{array}$ & - & $\begin{array}{l}\text { Kegiatan rutin pada jam } \\
06.30 \text { yang berbeda-beda } \\
\text { antar hari Senin sampai } \\
\text { Sabtu } \\
\text { Ada kegiatan bersalaman } \\
\text { sebelum masuk kelas } \\
\text { dan gur menyentuh } \\
\text { ubun-ubun peserta didik } \\
\text { sembari mendoakan }\end{array}$ & \\
\hline $\begin{array}{l}\text { Strategi atau program dalam Penguatan } \\
\text { Pendidikan Karakter dalam membentuk } \\
\text { suritauladan bagi peserta didik }\end{array}$ & $\begin{array}{l}\text { Menjalin hubungan yang } \\
\text { baik antar warga sekolah }\end{array}$ & - & $\begin{array}{l}\text { Adanya pembiasaan } \\
\text { yang terlebih dahulu } \\
\text { dilakukan oleh guru }\end{array}$ & \\
\hline $\begin{array}{l}\text { Strategi atau program dengan melibatkan } \\
\text { seluruh pemangku kepentingan (sekolah, } \\
\text { keluarga, masyarakat) dalam Penguatan } \\
\text { Pendidikan Karakter }\end{array}$ & $\begin{array}{l}\text { Pemberian ruang yang } \\
\text { baik bagi orang tua dalam } \\
\text { mendukung PPK } \\
\text { Bekerjasama dengan } \\
\text { pihak terkait }\end{array}$ & & $\begin{array}{l}\text { belum ada program } \\
\text { khusus namun orangtua } \\
\text { selalu mendukung } \\
\text { program sekolah }\end{array}$ & \\
\hline $\begin{array}{l}\text { Strategi atau program dalam Penguatan } \\
\text { Pendidikan Karakter dalam hal } \\
\text { membangun, mematuhi norma, peraturan } \\
\text { dan tradisi sekolah } \\
\text { Mungkin bisa terkait dengan tata tertib } \\
\text { untuk guru ataupun tata tertib untuk sisiwa. }\end{array}$ & $\begin{array}{l}\text { Adanya sanksi yang } \\
\text { mengandung nilai } \\
\text { karakter jika melanggar } \\
\text { peraturan }\end{array}$ & & $\begin{array}{l}\text { Pemberian sanksi yang } \\
\text { mendidik bagi yang } \\
\text { melanggar }\end{array}$ & \\
\hline $\begin{array}{l}\text { strategi atau program dalam Penguatan } \\
\text { Pendidikan Karakter terkait dengan literasi }\end{array}$ & $\begin{array}{l}\text { Ada gerakan gemar } \\
\text { membaca setiap hari } \\
\text { jumat }\end{array}$ & & $\begin{array}{l}\text { Ada program } 15 \text { menit } \\
\text { setiap hari sebelum } \\
\text { pelajaran dimulai untuk } \\
\text { membaca buku bebas }\end{array}$ & \\
\hline
\end{tabular}


Tabel 3. Hasil Fokus Masalah 3

\begin{tabular}{|c|c|c|c|c|}
\hline \multirow[t]{2}{*}{ Pertanyaan } & \multicolumn{2}{|l|}{ Siklus I } & \multicolumn{2}{|l|}{ Siklus II } \\
\hline & Persamaan & Perbedaan & Persamaan & Perbedaan \\
\hline Faktor Pendukung dan & Faktor Pendukung & - & Faktor Pendukung Internal & \\
\hline Penghambat Keberhasilan & Internal & & Ada Guru dan peserta didik yang & \\
\hline Penguatan Pendidikan Karakter & Adanya dukungan dari & & sadar akan pentingnya karakter & \\
\hline & sekolah untuk PPK & & Faktor Pendukung Eksternal & \\
\hline & Faktor pendukung & & Kesadaran dari wali murid yang & \\
\hline & eksternal & & terlibat aktif dalam PPK & \\
\hline & serta menbantu PPK & & ada beberapa guru dan peserta didik & \\
\hline & Faktor penghambat & & yang kurang sadar akan pentingnya & \\
\hline & Internal & & PPK & \\
\hline & Ada guru yang kurang & & Faktor penghambat eksternal & \\
\hline & paham akan nilai & & Adanya beberapa wali murid yang & \\
\hline & karakter & & acuh tak acuk terhadap penguatan & \\
\hline & Ada beberapa peserta & & pendidikan karakter anaknaya & \\
\hline & Fasilitas sekolah & & & \\
\hline & Faktor penghambat & & & \\
\hline & eksternal & & & \\
\hline & Orangtua yang kurang & & & \\
\hline & perhatian terhadap & & & \\
\hline & anaknya & & & \\
\hline
\end{tabular}

\section{PEMBAHASAN}

Strategi Dan Impelementasi Penguatan Pendidikan Karakter Berbasis Kelas Di SD Muhammadiyah 08 Dau Dan MI Miftahul Ulum Sudimoro adalah Strategi atau program dalam penguatan pendidikan karakter terkait visi dan misi sekolah di SD Muhammadiyah 08 DAU dan MI Miftahul Ulum Sudimoro adalah memasukkan atau membuat beberapa program, SD Muhammadiyah 08 Dau dan MI Miftahul Ulum Sudimoro memiliki guru yang selalu menggunakan model dan metode pembelajaran yang bermacam-macam dan saling mengkolaborasikan. Modifikasi model pembelajaran yang mengacu pada Pengembangan Kompetensi Dasar menunjang peserta didik untuk termotivasi mengikuti proses belajar mengajar dengan baik (Judiani, 2010). Di SD Muhammadiyah 08 Dau maupun di MI Miftahul Ulum Sudimoro, SD Muhammadiyah 08 Dau, dan MI Miftahul Ulum Sudimoro juga menggunakan teknik penataan bangku, baik secara tradisional maupun secara kelompok. Pengelolaan kelas juga berbentuk non fisik yaitu diantaranya adalah dilihat bagaiamana peserta didik berinteraksi dengan peserta didik lainnya, peserta didik dengan guru, strategi atau program untuk Penguatan Pendidikan Karakter (PPK) dalam merencanakan peraturan kelas di SD Muhammadiyah 08 Dau dan MI Miftahul Ulum Sudimoro ini ini menggunakan strategi penyesuaian dengan karakteristik peserta didik, mengandung nilai religius, nasionalis, gotong royong, mandiri, integritas, dan adanya hukuman bagi yang melanggar.

Prosedur pengelolaan pekerjaan peserta didik memiliki strategi khusus dalam Penguatan Pendidikan Karakter (PPK) di SD Muhammadiyah 08 Dau, yaitu dengan cara melakukan komunikasi kepada peserta didik. Komunikasi ini gunanya untuk mempertegas pekerjaan apa yang akan dilakukan oleh peserta didik tersebut dan jika di MI Miftahul Ulum Sudimoro strategi dan implementasi pengelolaan pekerjaan peserta didik dapat dilakukan dengan cara pemberian hukuman bagi yang tidak mengerjakan tugas, disini peserta didik biasanya diberikan denda sebesar Rp. 500,- apabila tidak mengerjakan pekerjaan rumahnya, Mengelola perilaku yang tidak pantas adalah salah satu strategi PPK dan implementasinya adalah peserta didik yang melakukan pelanggaran di kelas SD Muhammadiyah 08 Dau diberikan teguran, nasehat dan hukuman yang mengandung nilai-nilai karakter seperti yang sudah dijelaskan diatas untuk hukumannya. Jika di MI Miftahul Ulum diberikan teguran bagi yang melangar tata tertib termasuk diantaranya melakukan perilaku yang tidak pantas. Karakter pada umumnya juga disebut juga dengan bertanggung jawab apa yang di lakukan seseorang dan bagaimana cara menyelesaikannya baik dengan keluarga maupun lingkungan sekitarnya (Ramadhani, 2017).

Strategi dan implementasi penguatan pendidikan karakter berbasis budaya sekolah di SD Muhammadiyah 08 Dau dan MI Miftahul Ulum adalah terdiri dari beberapa aspek termasuk diantaranya cara menanamkan nilai-nilai utamanya dari segi religious, integritas, nasionalis, gotong royong, mandiri yang dilakukan dalam kegiatan sehari hari SD Muhammadiyah 08 Dau memiliki kegiatan yang dapat mengembangkan Penguatan Pendidikan Karakter (PPK) peserta didik. Termasuk diantarnaya ada kegiatan kegiatan rutin harian berbaris di depan kelas menumbuhkan karakter disiplin, kegiatan sholat Dhuha yang 
implentasiannya dilakukan setiap hari dari hari Senin—Jumat diikuti peserta didik dari kelas 1 - 6 diadakan di masjid sekolah, upacara bendera saat hari Senin dilakukan di halaman sekolah SD Muhammadiyah 08 Dau, menyanyikan lagu kebangsaan Indonesia Raya menumbuhkan karakter nasionalis yang dilakukan setiap hari sebelum proses pembelajaran, membaca Asmaul Husna menumbuhkan karakter religius, program senyum, salam, sapa ada kegiatan Jumat Bersih, ada program Tahfidzul Qur'an yang dilaksanakan pada hari Senin sampai dengan Kamis jam 07.30 - 07.50 tergantung level bacaan peserta didik dilakukan di kelas masing-masing, kegiatan ekstrakurikuler tapak suci, Hisbul Wathan, karawitan, Jalan santai, ada pula gerakan gemar membaca pada hari Jum'at.

MI Miftahul Ulum Sudimoro juga memiliki strategi dan implementasi Penguatan Pendidikan Karakter (PPK) termasuk diantaranya adalah kegiatan rutin pada jam 06.30 yang berbeda-beda antara hari senin sampai sabtu, upacara bendera setiap hari Senin, Selasa ada upacara senam asmaul husna, Rabu ada kegiatan Istigosah, Kamis ada kegiatan sholat dhuha, Jumat ada kegiatan senam santri, Sabtu ada kegiatan senam SKJ, anak masuk kedalam kelas guru berbaris dan peserta didik berbaris di depan kelas, lalu masuk bersalaman dengan guru dengan ditepuk pundaknya sembari didoakan, mendoakan anak supaya menjadi pintar dan anak mengucapkan amin lalu masuk kedalam kelas, itu salah satu dari pembiasaan kedua Strategi dan implementasi Penguatan Pendidikan Karakter (PPK) dalam hal membentuk suritauladan bagi peserta didik pada dasarnya SD Muhammadiyah 08 Dau Malang dan MI Miftahul Ulum Sudimoro memiliki kesamaan yaitu guru dituntut untuk melakukan pembiasaan yang baik untuk peserta didik, nantinya cepat atau lambat peserta didik akan mengikuti guru tersebut ketiga strategi dan implentasi PPK di SD Muhammadiyah 08 Dau memiliki strategi yaitu memberikan ruang kepada wali murid untuk berkomunikasi dengan guru, misalnya dengan pembentukan grub WA, lalu bekerjasama dengan pihak UMM untuk mengadakan seminar-seminar pelatihan. Untuk MI Miftahul Ulum Sudimoro sendiri belum ada program khusus, melainkan jika ada program sekolah yang terkait dengan kehadirian wali murid pasti wali murid datang ke sekolah keempat SD Muhammadiyah 08 Dau memiliki aturan sekolah dimana yang melanggar akan mendapatkan sanksinya tentunya sanksi ini mengandung nilai penguatan pendidikan karakter yaitu menulis surah dalam Al Qur'an terkait dengan literasi ada gerakan gemar membaca yang dilaksanakn setiap hari Jumat.

MI Miftahul Ulum Sudimoro ini juga mensosialisasikan terlebih dahulu aturan yang sudah disepakati lalu diadakan sanksi bagi yang melanggar, untuk literasi ada gerakan 15 menit sebelum pelajaran dimulai maka ada kegiatan membaca. Membaca buku bebas. Faktor pendukung dan penghambat keberhasilan penguatan pendidikan karakter di SD Muhammadiyah 08 Dau dan MI Miftahul Ulum Sudimoro Pengimplementasian pengguatan pendidikan karakter tentunya tidak akan berjalan dengan mulus. Ketika banyak faktor yang tidak medukung maka Penguatan Pendidikan Karakter (PPK) akan berjalan dengan baik dan begitu juga sebaliknya ketika banyak faktor yang menghambat maka pelaksanaan Penguatan Pendidikan Karakter (PPK) juga akan terkendala. Pelaksanaan PPK di SD Muhammadiyah 08 Dau tentunya memiliki faktor pendukung dan penghambat internal dan eksternal. Faktor pendukung internalnya adalah adanya dukungan dari sekolah untuk PPK contohnya adalah Sekolah mendukung adanya peraturan yang ada di kelas, sekolah memberikan fasilitas kepada guru dalam mengikuti seminar PPK serta sekolah memberikan fasilitas literasi dalam PPK di setiap kelas sedangkan untuk faktor pendukung eksternal adalah Pemangku kepentingan seperti komite membantu mensosialisaikan pentingnya Penguatan Pendidikan Karakter (PPK) kepada orangtua, terdapat orangtua yang berperan aktif dalam penguatan pendidikan karakter peserta didik kolaborasi dengan guru kelas, faktor lingkungan sebagian rumah peserta didik dalam kelas tersebut yang sangat menanamkan nilai karakter, adanya interaksi yang positif antara orangtua dengan sekolah serta wali murid yang ikut serta membantu Penguatan Pendidikan Karakter (PPK). Ada pula faktor penghambat Internal adalah sekolah memiliki keterbatasan waktu untuk diadakannya pelatihan guru kelas dalam Penguatan Pendidikan Karakter (PPK), terdapat peserta didik di kelas yang sulit untuk diajak berkarakter yang baik, sarana dan prasarana dalam mengembangkan nilai karakter kurang terjaga dengan baik, kurangnya pendanaan karena sekolah swasta serta ada sebagian peserta didik yang mungkin kurang memiliki inisiatif untuk melakukan perbuatan sesuai dengan nilai-nilai karakter dan yang terakhir faktor penghambat eksternal adalah Adanya peserta di kelas yang orangtuanya sibuk bekerja sehingga penguatan pendidikan karakter peserta didik ini kurang diperhatikan, faktor lingkungan yang saat ini masih kental dengan budaya jaranan yang kurang mendukung dalam penguatan pendidikan karakter dan juga masih banyak orangtua yang kurang mendukung dalam kebijakan sekolah terkait penguatan pendidikan karakter ini.

Untuk MI Miftahul Ulum Sudimoro juga memiliki faktor internal dan eksternal serta pendukung dan penghambat faktor pendukung secara internal adalah guru sebagai teladan, peserta didik yang rajin atau berkarakter baik. Sedangkan pendukung secara eksternalnya adalah orang tua selalu mendukung kegiatan peserta didik. Adapun faktor penghambat secara internal adalah ada guru yang teledor, guru meninggalkan kelas dan sarana dan prasarana yang kurang sedangkan secara eksternal adalah beberapa wali murid yang kurang perhatikan terhadap pendidikan karakter anaknya. Menurut (Krisnawanti, 2016) Diperlukannya partisipasi dari semua belah pihak guna mewujudkan pengguatan pendidikan karakter yang sedang berlangsung pada diri peserta didik. 


\section{SIMPULAN}

Strategi dan implementasi penguatan pendidikan karakter disekolah berbasis kelas maupun berbasis budaya sekolah adalah salah satu caranya. Penguatan pendidikan karakter berbasis kelas masuk kedalam beberapa cara baik di SD Muhammadiyah 08 Dau maupun di MI Miftahul Ulum Sudimoro. Cara tersebut diantaranya terkait dengan perumusan visi dan misi, terkait juga dengan analisis kompetensi dasar, terkait dengan perencanaan pembelajaran, dengan pengaturan ruang kelas, dengan merencanakan peraturan kelas, prosedur penggelolaan pekerjaan peserta didik dan juga menggelola prilaku peserta didik yang tidak pantas.

Strategi dan implementasi penguatan pendidikan karakter berbasis budaya sekolah contohnya baik di SD Muhammadiyah 08 Dau maupun di MI Miftahul Ulum Sudimoro terimplementasi kedalam beberapa program baik sasaranya untuk peserta didik maupun untuk guru. Keberhasilan SD Muhammadiyah 08 Dau maupun di MI Miftahul Ulum Sudimoro tentunya memiliki faktor pendukung dan penghambat dalam penguatan pendidikan karakter dimana masing masing faktor memiliki dua komponen yaitu faktor internal dan eksternal. Semua program yang teraplikasi yang sebelumnya dirancang tentunya mempertimbangkan atau dilandasi dengan lima nilai karakter yaitu religius, nasionalis, intregritas, mandiri dan juga gotong royong.

\section{DAFTAR RUJUKAN}

Andiarini, S. E., \& Nurabadi, A. (2018). Implementasi Program Penguatan Pendidikan Karakter melalui Kegiatan Pembiasaan Dalam Peningkatan Mutu Sekolah. JAMP: Jurnal Administrasi dan Manajemen Pendidikan, 1(2), 238-244.

Asriani, P., \& Sa'dijah, C. (2017). Bahan Ajar Berbasis Pendidikan Karakter untuk Siswa Kelas IV Sekolah Dasar. Jurnal Pendidikan: Teori, Penelitian, dan Pengembangan, 2(11), 1456-1468.

Dalimunthe, R. A. A. (2015). Strategi dan Implementasi Pelaksanaan Pendidikan Karakter di SMP N 9 Yogyakarta. Jurnal Pendidikan Karakter, 5(1), 102-111. https://doi.org/10.21831/jpk.v0i1.8616

Isbadrianingtyas, N., Hasanah, M., \& Mudiono, A. (2016). Pengelolaan Kelas dalam Pembelajaran Tematik di Sekolah Dasar. Jurnal Pendidikan: Teori, Penelitian, dan Pengembangan, 1(5), 901-904.

Judiani, S. (2010). Implementasi Pendidikan Karakter di Sekolah Dasar melalui Penguatan Pelaksanaan Kurikulum. 16(April).

Krisnawanti, A. (2016). Kerjasama Guru Dengan Orangtua Membentuk Karakter Disiplin Siswa Kelas V SD Negeri Gembongan. BASIC EDUCATION, 5(18), 1-737.

Kurniawan, M. I. (2015). Tri Pusat Pendidikan sebagai Sarana Pendidikan Karakter Anak Sekolah Dasar. Journal Pedagogia, 4 (1), 41-49.

Manullang, B. (2013). Grand Desain Pendidikan Karakter Generasi Emas 2045. Jurnal Pendidikan Karakter, 3(1).

Puri, L. W., Nurkholipah, S., \& Putri, R. N. A. W. (2017). Peran Konselor Dalam Mengembangkan Budaya Sekolah Berbasis Karakter. Jurnal Pendidikan: Teori, Penelitian, dan Pengembangan, 2(5), 599-603.

Ramadhani, I. (2017). Kontribusi Adversity Quotient, Self Efficacy, Kreativitas dan Peran Orangtua terhadap Intesi Berwirausaha Berbasis Teknologi Siswa SMK Paket Keahlian Multimedia Se-Kota Malang. Tesis tidak diterbitkan. Universitas Negeri Malang, Malang.

Shoimah, L., Sulthoni, S., \& Soepriyanto, Y. (2018). Menanamkan Pendidikan Karakter melalui Pembiasaan di Sekolah. Jurnal Kajian Teknologi Pendidikan, 1(2), 169-175.

Wijanarti, W., Degeng, I. N. S., \& Untari, S. (2019). Problematika Pengintegrasian Penguatan Pendidikan Karakter pada Pembelajaran Tematik. Jurnal Pendidikan: Teori, Penelitian, dan Pengembangan, 4(3),393-398. 